\title{
Enzyme Activity in the Nervous Tissue of Lymnaea Acuminata Fed to Different Bait Formulations
}

\author{
Pradeep Kumar, V. K. Singh, D. K. Singh* \\ Malacology Laboratory, Department of Zoology, DDU Gorakhpur University, Gorakhpur, 273009, U.P. India
}

\begin{abstract}
Lymnaeid snails transmit medical and veterinary trematodiases, mainly fascioliasis. Vector specificity of fasciolid parasites defines disease distribution and characteristics. Control of fascioliasis is to de-link the life cycle of fluke, by destroying the Lymnaeid snails. Different Bait formulations were fed to snail Lymnaea acuminata in clear glass aquaria having diameter of $30 \mathrm{~cm}$. Snail attractant containing bait formulations were prepared from different binary combination of amino acid (valine, aspartic acid, lysine and alanine $10 \mathrm{mM})$ in $100 \mathrm{ml}$ of $2 \%$ agar solution + sub-lethal $(20 \%$ and $60 \%$ of $24 \mathrm{~h}$ $\mathrm{LC}_{50}$ and $96 \mathrm{hLC}_{50}$ ) doses of different molluscicides (eugenol, ferulic acid, umbelliferone, and limonene). Snails were fed bait with sub-lethal concentration of different molluscicides inside the snail attractant pellets, which caused a significant inhibition in alkaline phosphatase (ALP) and acetylcholinesterase (AChE) activity in the nervous tissue of the vector snail $L$. acuminata. Combination of different amino acids such as valine + aspartic acid, lysine + valine, lysine + alanine and alanine + valine was used as attractant with active molluscicidal components. Maximum inhibition in ALP (23.57\% of control) and $\mathrm{AChE}$ (49.48\% of control) activity were observed in the nervous tissue of the L. acuminata exposed to $60 \%$ of $96 \mathrm{~h} \mathrm{LC}_{50}$ of ferulic acid, umbelliferone, respectively in the bait pellets containing valine + aspartic acid as attractant.
\end{abstract}

Keywords Molluscicides, Amino Acids, Bait Formulation, Ache, Alkaline Phosphatase, Lymnaea Acuminata

\section{Introduction}

Fasciola hepatica and F. gigantica are the causative agent of endemic fascioliasis in different parts of the world[1]. Normally fascioliasis is reported in live-stock animals now more occurrence of fascioliasis in human population is noted in different part of the world[2,3]. Human fascioliasis is characterized by hypereosinophilia, abdominal pain and, exceptionally, acute pancreatitis[4,5]. One way to reduce the incidence of fascioliasis is to de-link the life cycle of fluke, by destroying the intermediate hosts[6-12]. Bait formulation of different molluscicides would be an effective tool for selective killing of the snail with minimal adverse effect on the non-target animal and environment. It is therefore important to identify strong attractant compounds and molluscicides for effective bait formulations. Use of a combination of snail attractant and molluscicides in bait formulation is an effective tool for the pest management. The present work is a continuation of our earlier studies[13,14]. The aim of the present study is to evaluate the effect of sub-lethal feeding molluscicides eugenol, ferulic acid, umbelliferone, and limonene[11] in bait formulations with attractant amino acid valine, aspartic acid, lysine and alanine[11] on different

* Corresponding author:

dksingh_gpu@yahoo.co.in (D. K. Singh)

Published online at http://journal.sapub.org/chemistry

Copyright (C) 2012 Scientific \& Academic Publishing. All Rights Reserved enzyme activity (alkaline phosphatase and AChE) in the nervous tissue of the L. acuminata. Snail L. acuminata is the intermediate host of Fasciola species.

\section{Materials and Methods}

\subsection{Collection of Snails}

Adult L. acuminata $(2.25 \pm 0.20 \mathrm{~cm}$ in length), intermediate host of liver fluke $F$. gigantica, was used as test animals in the present study. The snails were collected locally from lakes and low lying submerged fields. These snails were acclimatized for 72 hours in dechlorinated tap water at $25 \pm 1^{\circ} \mathrm{C}$. The $\mathrm{pH}$ of the water was 7.1-7.3 and dissolved oxygen, free carbon dioxide and bicarbonate alkalinity were 6.5-7.2 mg/1, 5.2-6.3 mg/l and 102.0-105.0 mg/1, respectively.

\subsection{Pure Compounds}

Agar-agar, amino acids (98.5\%) (valine, aspartic acid, lysine and alanine; CDH, New Delhi, India), different active molluscicidal component such as eugenol, ferulic acid, umbelliferone and limonene were used in bait formulation. The pure active component ferulic acid (99\%) (4 - Hydroxy - 3 methoxycinnamic), umbelliferone (99\%) (7- Hydroxy coumarin; 7 - hydroxy - $2 \mathrm{H}-1$ - benzopyran-2-one), eugenol (99\%) (2-Methoxy-4-(2-propenyl) phenol) and limonene (97\%) (R)-4-Isopropenyl-1-methyl-1-cyclohexene); were 
purchased from Sigma Chemical Co. (USA).

\subsection{Preparation of Bait Formulations}

Bait formulations containing binary combination of different amino acid (valine, aspartic acid, lysine and alanine $10 \mathrm{mM})$ and sub lethal $\left(20 \%\right.$ and $60 \%$ of $24 \mathrm{~h}$ and $\left.96 \mathrm{~h} \mathrm{LC}_{50}\right)$ concentration of molluscicides were prepared in $100 \mathrm{ml}$ of $2 \%$ agar solution by the method of Madsen,[15]. Concentrations of amino acids were based on the earlier reports of Tiwari and Singh[16,17]. These solutions were spread at a uniform thickness of $5 \mathrm{~mm}$. After cooling the bait containing sublethal molluscicides were cut out a corer measuring $5 \mathrm{~mm}$ in diameter.

\subsection{Assay Apparatus and Procedure}

The bioassay was performed by the method by Tiwari and Singh[16,17]. The bioassay chamber consists of a clean glass aquarium having a diameter of $30 \mathrm{~cm}$. Each aquarium was divided into four concentric zones with diameters of 13, 18, 24 and $30 \mathrm{~cm}$ : Central zone (zone3), Middle zone (zone2 and 1) and Outer zone (zone0). A small annular elevation of 9 $\mathrm{mm}$ height and $2.4 \mathrm{~cm}$ diameter was made in the centre of aquarium (Zone 3). Zone 0 had an area of $254 \mathrm{~cm}^{2}$ on the periphery of aquarium. The aquaria were then filled with 500 $\mathrm{ml}$ of dechlorinated tap water to a height of $8 \mathrm{~mm}$ and maintained at $25 \pm 1^{\circ} \mathrm{C}$. At the start of the assay ten individually marked snails of uniform size were placed on the circumference of zone 0 . The distance between two snails was $66 \mathrm{~mm}$. Simultaneously, one of the prepared bait containing sublethal concentration of different active molluscicidal components were added on the small annular elevation in the center (Zone 3). Six sets of experiments have been designed with ten snails each for all molluscicides used in this study.

\subsection{Biochemical Estimations}

After $24 \mathrm{~h}$ of bait feeding the snails were washed with water and the nervous tissue was dissected out from snail brain and used for the measurement of enzyme activities. Different enzyme activity viz. alkaline phosphatase (ALP) and acetylcholinesterase (AChE) were measured in feeding as well as control group of snails.

In withdrawal experiment ALP and AChE activity in the nervous tissue of snail were measured in withdrawan snails after $96 \mathrm{~h}$ feeding of $60 \%$ of $96 \mathrm{~h} \mathrm{LC}_{50}$ of bait for next $72 \mathrm{~h}$ to fresh water.

\subsection{Alkaline Phosphatase Activity}

The alkaline phosphatase activity was measured by the method of Bergmeyer[18] as modified by Singh and Agarwal[19]. The nervous tissue was homogenized $(2 \% \mathrm{w} / \mathrm{v})$ in ice cold $0.9 \% \mathrm{NaCl}$ and centrifuged at $5000 \mathrm{xg}$ for 20 minutes at $4^{\circ} \mathrm{C}$. Standard curves were drawn with p-nitrophenol. 0.1 $\mathrm{ml}$ of enzyme source supernatant was added in $1.0 \mathrm{ml}$ of alkaline buffer substrate solution (prepared by dissolving $375 \mathrm{mg}$ glycine, $10 \mathrm{mg} \mathrm{MgCl}_{2} .6 \mathrm{H}_{2} \mathrm{O}$ and $165 \mathrm{mg}$ p- nitrophenyl phosphate sodium salt in $42 \mathrm{ml}$ of $0.1 \mathrm{~N} \mathrm{NaOH}$ and mixture was made upto $100 \mathrm{ml}$ with double distilled water). The mixture was mix thoroughly and incubated for $30 \mathrm{~min}$. at $37^{\circ} \mathrm{C} .10 \mathrm{ml}$ of $0.02 \mathrm{~N} \mathrm{NaOH}$ was added to the incubation mixture. The reaction was stopped by addition of an excess of $\mathrm{NaOH}$. The alkaline phospahatase activity was measured colorimetrically at $420 \mathrm{~nm}$ which is a measure of yellow colour of nitrophenol produced by the hydrolysis of p-nitrophenyl phosphate buffer. The enzyme activity was expressed in $\mu$ moles substrate hydrolyzed $/ 30 \mathrm{~min} / \mathrm{mg}$ protein.

\subsection{Acetylcholinesterase}

Acetylcholinesterase activity was measured by the method of Ellman et al.,[20] as modified by Singh and Agarwal[21]. The nervous tissue of $L$. acuminata was homogenized (50 $\mathrm{mg} / \mathrm{ml}$ ) in $0.1 \mathrm{M}$ phosphate buffer ( $\mathrm{pH} 8.0$ ) for 5 minutes in an ice bath and centrifuged at $1000 \mathrm{xg}$ for 30 minutes at $4^{\circ} \mathrm{C}$. The clear supernatant was taken as an enzyme source. The enzyme activity was measured in a $10 \mathrm{~mm}$ path-length cuvette using incubation mixture consisting of $0.1 \mathrm{ml}$ of enzyme source, $2.9 \mathrm{ml}$ of $0.1 \mathrm{M}$ phosphate buffer ( $\mathrm{pH} 8.0$ ); 0.1 $\mathrm{ml}$ of chromogenic agent DTNB (5, 5-dithiobis-2- nitrobenzoate) and $0.2 \mathrm{ml}$ of freshly prepared acetylthiocholine iodide. The change in optical density at $412 \mathrm{~nm}$ was continuously observed on spectrophotometer for 3 minutes at $25^{\circ} \mathrm{C}$. Enzyme activity was expressed as $\mu$ moles $\mathrm{SH}$ hydrolyzed/minute/mg protein.

\subsection{Statistical Analysis}

Each result was six times replicate estimation (measurement in six different pool of nervous tissue). The values were expressed as Mean \pm SE. Student's t-test was applied to determine the significant $(\mathrm{P}<0.05)$ difference between treated and control animals[22].

\section{Results}

Sub-lethal feeding to $20 \%$ and $60 \%$ of $24 \mathrm{~h}$ and $96 \mathrm{~h}_{50}$ of ferulic acid, umbelliferone, eugenol and limonene in bait formulations caused a significant $(\mathrm{P}<0.05)$ inhibition in alkaline phosphatase activity in the nervous tissue of snail $L$. acuminata (Table-1).

Maximum inhibition (23.57\% of control) in alkaline phosphatase activity was observed in the nervous tissue of $L$. acuminata fed to $60 \%$ of $96 \mathrm{~h} \mathrm{LC}_{50}$ of ferulic acid (Table-1). Significant $(\mathrm{P}<0.05)$ recovery in alkaline phosphatase activity was observed in the nervous tissue of $L$. acuminata earlier fed to $60 \%$ of $96 \mathrm{~h}_{50}$ of ferulic acid bait $(23.57 \%$ of control), when discontinued for the next $72 \mathrm{~h}$ ( $38.43 \%$ of control). The sub-lethal feeding to $20 \%$ and $60 \%$ of $24 \mathrm{~h} \mathrm{CC}_{50}$ and $96 \mathrm{~h}$ $\mathrm{LC}_{50}$ of eugenol, ferulic acid, umbelliferone and limonene caused a significant inhibition in the AChE activity in the nervous tissue of the snail L. acuminata (Table-2).

Maximum inhibition $(49.48 \%$ of control) in the AChE activity was observed in the nervous tissue of the snail fed to $60 \%$ of $96 \mathrm{LC}_{50}$ of umbelliferone containing bait (Table-2). 
There was a significant $(\mathrm{P}<0.05)$ recovery in the AChE activity in the nervous tissue of $72 \mathrm{~h}$ withdrawn $(57.77 \%)$ snails with respect to snails fed to $60 \%$ of $96 \mathrm{~h} \mathrm{LC}_{50}$ of umbelliferone bait.

Table.1. Effect of sublethal exposure (20\% and $60 \%$ of $24 \mathrm{~h} \mathrm{LC} 50$ and $\left.96 \mathrm{~h} \mathrm{LC}_{50}\right)$ of bait formulation with active molluscicidal component (ferulic acid, umbelliferone, eugenol and limonene) on the level of alkaline phosphatase (ALP) activity in the nervous tissue of L. acuminata

\begin{tabular}{|c|c|c|c|c|c|}
\hline \multirow{2}{*}{ Treatment } & \multicolumn{2}{|c|}{$24 \mathrm{~h} \mathrm{LC}_{50}$} & \multicolumn{2}{|c|}{$96 \mathrm{~h} \mathrm{LC}_{50}$} & \multirow{2}{*}{$\begin{array}{c}\text { Withdrawal } \\
60 \% \\
\end{array}$} \\
\hline & $20 \%$ & $60 \%$ & $20 \%$ & $60 \%$ & \\
\hline Control (Agar) & \multicolumn{4}{|c|}{$\begin{array}{c}2.69 \pm 0.31 \\
(100)\end{array}$} & $2.13 \pm 0.68(100)$ \\
\hline Control (a) & \multicolumn{4}{|c|}{$2.63 \pm 0.82$} & \\
\hline Vali+Aspa & \multicolumn{4}{|c|}{$\begin{array}{c}(100) \\
275 \pm 019\end{array}$} & 0.6 \\
\hline Control (b) & \multirow{2}{*}{\multicolumn{4}{|c|}{$\begin{array}{c}2.75 \pm 0.19 \\
(100)\end{array}$}} & \\
\hline Lysi+Vali & & & & & $2.06 \pm 0.38(100)$ \\
\hline Control (c) & \multicolumn{4}{|c|}{$2.55 \pm 0.18$} & $2.8 \times-2=0$ \\
\hline Lysi+Ala & \multicolumn{4}{|c|}{$(100)$} & 2.8 \\
\hline Control (d) & \multirow{2}{*}{\multicolumn{4}{|c|}{$\begin{array}{c}2.45 \pm 0.32 \\
(100)\end{array}$}} & $211+018(100)$ \\
\hline Ala+Vali & & & & & \\
\hline Vali+Aspa+Eug & $1.86 \pm 0.09 *(70.72)$ & $1.32 \pm 0.15^{*}(50.19)$ & $1.55 \pm 0.08 *(58.93)$ & $1.12 \pm 0.04 *(42.58)$ & $1.81 \pm 0.03+(70.98)$ \\
\hline Vali+Aspa+Fer & $1.11 \pm 0.02 *(42.20)$ & $0.96 \pm 0.09 *(36.50)$ & $0.86 \pm 0.11 *(32.69)$ & $0.62 \pm 0.21 *(23.57)$ & $0.98 \pm 0.32+(38.43)$ \\
\hline Vali+Aspa+Umb & $0.89 \pm 0.06 *(33.84)$ & $0.76 \pm 0.10 *(28.89)$ & $0.85 \pm 0.06 *(32.31)$ & $0.80 \pm 0.06 *(30.41)$ & $0.88 \pm 0.05+(34.50)$ \\
\hline Vali+Aspa+lim & $1.62 \pm 0.07 *(61.59)$ & $1.10 \pm 0.08 *(41.82)$ & $0.98 \pm 0.16 *(37.21)$ & $0.80 \pm 0.32 *(30.41)$ & $0.99 \pm 0.13+(38.82)$ \\
\hline Lysi+Vali+Eug & $1.75 \pm 0.19 *(63.63)$ & $0.96 \pm 0.06 *(34.20)$ & $0.86 \pm 0.12 *(31.27)$ & $0.76 \pm 0.19 *(27.63)$ & $0.98 \pm 0.10+(36.84)$ \\
\hline Lysi+Vali+Fer & $1.04 \pm 0.03 *(37.81)$ & $0.96 \pm 0.12 *(34.90)$ & $0.98 \pm 0.62 *(35.63)$ & $0.82 \pm 0.06 *(29.81)$ & $0.99 \pm 0.03+(37.21)$ \\
\hline Lysi+Vali+Umb & $1.30 \pm 0.40 *(47.27)$ & $0.97 \pm 0.04 *(35.27)$ & $0.96 \pm 0.03 *(34.90)$ & $0.82 \pm 0.08 *(29.81)$ & $0.98 \pm 0.32+(36.84)$ \\
\hline Lysi+Vali+Lim & $1.11 \pm 0.22 *(40.36)$ & $0.98 \pm 0.62 *(35.63)$ & $0.90 \pm 0.04 *(32.72)$ & $0.80 \pm 0.12 *(29.09)$ & $0.92 \pm 0.62+(34.58)$ \\
\hline Lysi+Ala+Eug & $1.89 \pm 0.04 *(46.27)$ & $0.97 \pm 0.06 *(38.03)$ & $0.95 \pm 0.07 *(37.25)$ & $0.85 \pm 0.09 *(33.33)$ & $0.98 \pm 0.10+(34.26)$ \\
\hline Lysi+Ala+Fer & $1.05 \pm 0.06 *(41.17)$ & $0.99 \pm 0.08 *(38.82)$ & $0.95 \pm 0.09 *(37.25)$ & $0.89 \pm 0.03 *(34.90)$ & $0.98 \pm 0.10+(34.26)$ \\
\hline Lysi+Ala+Umb & $0.88 \pm 0.06 *(34.50)$ & $0.82 \pm 0.03 *(32.15)$ & $0.80 \pm 0.17 *(31.37)$ & $0.76 \pm 0.33 *(25.60)$ & $0.81 \pm 0.12+(28.32)$ \\
\hline Lysi+Ala+Lim & $1.60 \pm 0.03 *(62.74)$ & $0.92 \pm 0.06 *(36.07)$ & $0.91 \pm 0.08 *(35.68)$ & $0.88 \pm 0.13 *(34.50)$ & $0.92 \pm 0.02+(32.16)$ \\
\hline Ala+Vali+Eug & $1.76 \pm 0.07 *(71.83)$ & $0.99 \pm 0.08 *(40.40)$ & $0.96 \pm 0.04 *(39.18)$ & $0.91 \pm 0.03 *(37.14)$ & $0.98 \pm 0.04+(46.44)$ \\
\hline Ala + Vali+Fer & $1.05 \pm 0.06 *(42.85)$ & $0.98 \pm 0.02 *(40.00)$ & $1.02 \pm 0.06 *(41.63)$ & $0.99 \pm 0.08 *(40.40)$ & $1.10 \pm 0.19+(52.13)$ \\
\hline $\mathrm{Ala}+$ Vali+Umb & $0.92 \pm 0.04 *(37.55)$ & $0.98 \pm 0.06 *(36.32)$ & $0.93 \pm 0.02 *(37.95)$ & $0.87 \pm 0.08 *(35.51)$ & $0.94 \pm 0.13+(44.54)$ \\
\hline Ala+Vali+Lim & $1.58 \pm 0.09 *(64.48)$ & $0.97 \pm 0.02 *(39.59)$ & $0.98 \pm 0.19 *(40.00)$ & $0.88 \pm 0.06 *(35.91)$ & $0.98 \pm 0.07+(46.44)$ \\
\hline
\end{tabular}

Each value is mean $\pm \mathrm{SE}$ of six replicates.

Value is parentheses are per cent change with control taken as $100 \%$.

Concentration $(\mathrm{w} / \mathrm{v})$ has been expressed as final concentration in aquarium water.

$\left.{ }^{*}\right)$ Significant $(\mathrm{P}<0.05)$ when't' test was applied in between treated and control group and $(+)$ in between $60 \%$ of $96 \mathrm{~h} \mathrm{LC}_{50}$ and withdrawal group.

Vali=valine, Aspa=aspartic acid, Lysi=lysine, Ala=alanine, Eug=euhenol, Feb=ferulic acid, Umb=umbelliferone, Lim=limonene

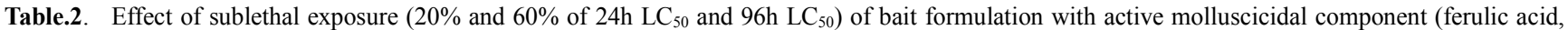
umbelliferone, eugenol and limonene) on the level of acetylcholinesterase (AchE) activity in the nervous tissue of L. acuminata

\begin{tabular}{|c|c|c|c|c|c|}
\hline \multirow{2}{*}{ Treatment } & \multirow{2}{*}{\multicolumn{2}{|c|}{$24 \mathrm{~h} \mathrm{LC}_{50}$}} & \multicolumn{2}{|c|}{$96 \mathrm{~h} \mathrm{LC}_{50}$} & \multirow{2}{*}{$\begin{array}{c}\text { Withdrawal } \\
60 \% \\
\end{array}$} \\
\hline & & & $20 \%$ & $60 \%$ & \\
\hline Control (Agar) & \multicolumn{4}{|c|}{$\begin{array}{c}0.098 \pm 0.006 \\
(100)\end{array}$} & $0.096 \pm 0.002(100)$ \\
\hline Control (a) & & 0.097 & 0.005 & & \\
\hline Vali+Aspa & & & & & $0.090 \pm 0.003(100)$ \\
\hline Control (b) & \multicolumn{4}{|c|}{$0.095 \pm 0.004$} & $0094+0007(100)$ \\
\hline Lysi+Vali & \multicolumn{4}{|c|}{$(100)$} & $0.094 \pm 0.00 /(100)$ \\
\hline Control (c) & \multicolumn{4}{|c|}{$0.097 \pm 0.003$} & \\
\hline Lysi+Ala & & & & & $0.096 \pm 0.005(10$ \\
\hline Control (d) & \multicolumn{4}{|c|}{$0.098 \pm 0.004$} & $0.095 \pm 0.003(100)$ \\
\hline Ala+Vali & \multicolumn{4}{|c|}{$(100)$} & \\
\hline Vali+Aspa+Eug & $0.072 \pm 0.003 *(74.22)$ & $0.068 \pm 0.006 *(70.10)$ & $0.067 \pm 0.005 *(69.07)$ & $0.062 \pm 0.008 *(63.91)$ & $0.078 \pm 0.002+(86.66)$ \\
\hline Vali+Aspa+Fer & $0.059 \pm 0.005 *(60.82)$ & $0.055 \pm 0.002 *(56.70)$ & $0.056 \pm 0.003 *(57.73)$ & $0.051 \pm 0.007 *(52.57)$ & $0.057 \pm 0.006+(63.33)$ \\
\hline Vali+Aspa+Umb & $0.060 \pm 0.004 *(61.85)$ & $0.052 \pm 0.009 *(53.60)$ & $0.051 \pm 0.006 *(52.52)$ & $0.048 \pm 0.002 *(49.48)$ & $0.052 \pm 0.007+(57.77)$ \\
\hline Vali+Aspa+lim & $0.072 \pm 0.006 *(74.20)$ & $0.068 \pm 0.003 *(70.10)$ & $0.066 \pm 0.008 *(68.04)$ & $0.060 \pm 0.004 *(61.85)$ & $0.065 \pm 0.005+(72.22)$ \\
\hline Lysi+Vali+Eug & $0.070 \pm 0.006 *(73.68)$ & $0.068 \pm 0.005 *(71.57)$ & $0.065 \pm 0.003 *(68.42)$ & $0.060 \pm 0.003 *(63.15)$ & $0.064 \pm 0.002+(68.08)$ \\
\hline Lysi+Vali+Fer & $0.060 \pm 0.002 *(63.15)$ & $0.056 \pm 0.009 *(58.94)$ & $0.054 \pm 0.007 *(56.84)$ & $0.050 \pm 0.004 *(52.63)$ & $0.053 \pm 0.006+(56.38)$ \\
\hline Lysi+Vali+Umb & $0.059 \pm 0.006 *(62.10)$ & $0.056 \pm 0.004 *(58.94)$ & $0.055 \pm 0.006 *(57.89)$ & $0.05 \pm 0.007 *(53.68)$ & $0.055 \pm 0.008+(58.51)$ \\
\hline Lysi+Vali+Lim & $0.070 \pm 0.003 *(73.68)$ & $0.066 \pm 0.006 *(69.47)$ & $0.063 \pm 0.003 *(66.31)$ & $0.059 \pm 0.002 *(62.10)$ & $0.061 \pm 0.004+(64.89)$ \\
\hline Lysi+Ala+Eug & $0.071 \pm 0.009 *(73.19)$ & $0.067 \pm 0.003 *(69.07)$ & $0.070 \pm 0.005 *(72.16)$ & $0.066 \pm 0.008 *(68.04)$ & $0.069 \pm 0.006+(71.87)$ \\
\hline Lysi+Ala+Fer & $0.060 \pm 0.003 *(61.85)$ & $0.058 \pm 0.008 *(58.79)$ & $0.056 \pm 0.007 *(57.73)$ & $0.052 \pm 0.006 *(53.60)$ & $0.055 \pm 0.003+(57.29)$ \\
\hline Lysi+Ala+Umb & $0.062 \pm 0.009 *(63.91)$ & $0.058 \pm 0.006 *(59.79)$ & $0.056 \pm 0.003 *(57.73)$ & $0.050 \pm 0.009 *(51.54)$ & $0.054 \pm 0.002+(56.25)$ \\
\hline Lysi+Ala+Lim & $0.071 \pm 0.004 *(73.19)$ & $0.068 \pm 0.005 *(70.10)$ & $0.066 \pm 0.007 *(68.04)$ & $0.060 \pm 0.004 *(61.85)$ & $0.067 \pm 0.008+(69.79)$ \\
\hline Ala+Vali+Eug & $0.069 \pm 0.006 *(70.40)$ & $0.065 \pm 0.003 *(66.32)$ & $0.061 \pm 0.005 *(62.24)$ & $0.058 \pm 0.003 *(59.18)$ & $0.062 \pm 0.009+(65.26)$ \\
\hline Ala+Vali+Fer & $0.060 \pm 0.003 *(61.22)$ & $0.058 \pm 0.008 *(59.18)$ & $0.053 \pm 0.006 *(54.08)$ & $0.050 \pm 0.006 *(51.02)$ & $0.054 \pm 0.007+(56.84)$ \\
\hline Ala+Vali+Umb & $0.062 \pm 0.007 *(63.26)$ & $0.058 \pm 0.003 *(59.18)$ & $0.055 \pm 0.003 *(56.12)$ & $0.051 \pm 0.004 *(52.04)$ & $0.056 \pm 0.003+(58.94)$ \\
\hline Ala+Vali+Lim & $0.071 \pm 0.005 *(72.44)$ & $0.068 \pm 0.004 *(69.38)$ & $0.065 \pm 0.006 *(66.32)$ & $0.061 \pm 0.007 *(62.24)$ & $0.064 \pm 0.005+(67.36)$ \\
\hline
\end{tabular}

Each value is mean $\pm \mathrm{SE}$ of six replicates.

Value is parentheses are per cent change with control taken as $100 \%$.

Concentration $(\mathrm{w} / \mathrm{v})$ has been expressed as final concentration in aquarium water

$(*)$ Significant $(\mathrm{P}<0.05)$ when ' $\mathrm{t}$ ' test was applied in between treated and control group and $(+)$ in between $60 \%$ of $96 \mathrm{~h} \mathrm{LC}_{50}$ and withdrawal group. Vali=valine,

Aspa=aspartic acid, Lysi=lysine, Ala=alanine, Eug=euhenol, $\mathrm{Feb}=$ ferulic acid, Umb=umbelliferone, $\mathrm{Lim}=$ limonene 


\section{Discussion}

It is evident from the result section that active components of Syzygium aromaticum (eugenol), Ferula asafoetida (ferulic acid, umbelliferone), and Carum carvi (limonene) in bait formulations were more effective in killing the L. acuminata. Earlier, it has been reported that direct release of eugenol, ferulic acid, umbelliferone, and limonene in aquarium water have significant molluscicidal activity again $L$. acuminata $[8$, 23]. Kumar and Singh[11, 12] have demonstrated that when these active molluscicidal components in bait formulations were fed to snails, it also acts as potent molluscicides. In present study mode of entry of molluscicides into the snail body is through the digestive system as it was used in bait. In an earlier study it was through the body surface when molluscicides were released directly in water[8]. Although the entry of molluscicide inside the body is different, both methods are equally effective in killing the snails. Snails fed with a sub-lethal dose i.e. $20 \%$ and $60 \%$ of $24 \mathrm{~h}$ and $96 \mathrm{~h} \mathrm{LC}_{50}$ of different molluscicides inside snail attractant pellets, caused a significant inhibition in ALP and AChE activity in the nervous tissue of snail $L$. acuminata. The inhibition in ALP and AChE activity may be due to the direct interference of these active molluscicidal with enzyme. Kumar et al.,[24] reported that there was a depletion of amino acid and reduction of protein and nucleic acid level in the ovotestis of $L$. acuminata when these active molluscicidel were fed to snails in bait formulations. Alkaline phosphatase plays a critical role in protein synthesis[25], shell formation[26] and other secretary activities[27] and its inhibition may result reduction in protein level[19, 28] in gastropods. It plays an important role in transport of metabolites across the membrane[29]. The AChE inhibition results in accumulation of acetylcholine at the nerves synapses, so that the post synaptic membrane is in a state of permanent stimulation producing paralysis, ataxia, and general lack of coordination in neuromuscular system and eventual death[30]. Animal behavior is a neurotropically regulated phenomenon which is mediated by neurotransmitter substances such as $\mathrm{ACh}[31]$. The enzyme AChE is found in the synaptic regions and mediates transmission of impulses by breaking acetylcholine into acetic acid and choline[32]. The acetylcholine at neural and neuromotor regions upon accumulation causes hyper-excitability[33] which in turn might also influence behavior pattern of animals. The present study shows that ferulic acids, umbelliferone, eugenol and limonene that are incorporated in the bait caused significant time and dose dependent inhibition in the activity of enzyme ALP and $\mathrm{AChE}$ in the snails L. acuminata. Although earlier it has been reported that ferulic acid, umbelliferone, eugenol and limonene inhibited the ALP and AChE activity in the nervous tissue of snails L. acuminata when used directly in aquarium water[23], yet it has been observed in the present study that inhibition of ALP activity in ferulic acid/limonene/eugenol bait fed snails were 1.09/1.26/1.60 times higher than earlier reports of Kumar et al.,[23]. Instead of it there is also difference in concentration of molluscicide in direct treatment ferulic acid/ umbelliferone/limonene and eugenol $(0.63,0.66$, 0.84 and $0.67 \mathrm{mg} / 1$, respectively) and bait formulations $(0.43$, $0.45,0.64$ and $0.45 \mathrm{mg} / \mathrm{l}$, respectively). The present study reveals that bait formulations are more appropriate in killing snails, with respect to direct release of molluscicides in aquatic environment. It is more economical and safe.

\section{ACKNOWLEDGMENTS}

One of the authors (Dr. Pradeep Kumar- Post Doctoral Fellow) is thankful to University Grants Commission, New Delhi, India for financial assistance.

\section{REFERENCES}

[1] Mas-Coma, S., M.A.Valero, and M.D. Bargues., 2009, Fasciola, Lymnaeids and human fascioliasis with a global overview on disease transmission, Epidemiology, evolutionary genetics. Molecular Epidemiology and control. In David Rollinson and Simon Iain Hay, Editors: Advances in Parasitology, Vol 69, Burlington: Academic Press., p 41-146

[2] Chen, M. G. and K. E. Mott., 1990, Progress in assessment of morbidity due to Fasciola hepatica infection: a review of recent literature. Tropical Diseases Bulletin., 87, R1-R38

[3] Mas-Coma, S., J. G. Esteban, and M. D. Bargues., 1999, Epidemiology of human fascioliasis: a review and proposed new classification. Bulletin of the World Health Organization., $77,340-346$

[4] Saba, R., M. Korkmaz., D. Inan., L. Mamikoglu., O. Turhan., F. Gunseren., C. Cevikol, and A. Kabaalioglu., 2004, Human fascioliasis. Clinical Microbiology and Infection., 10, 385-397

[5] Echenique-Elizondo, M., J. Amondarain, and C. Liron de Robles., 2005, Fascioliasis: an exceptional cause of acute pancreatitis. Journal of the Pancreas., 6, 36-39

[6] Godan, D., 1983, Pests slugs and snail biology and control, Edited by Dora Godan, translated by Sheila Gruber (Springer verlong Berlin, Heidelberg, New York)

[7] Marston, A. and K. Hostettmann., 1985, Plant molluscicides. Phytochemistry., 24, 639-652

[8] Kumar, P, and D.K. Singh., 2006, Molluscicidal activity of Ferula asafoetida, Syzygium aromaticum and Carum carvi and their active components against the snail Lymnaea acuminata. Chemosphere., 63,1568-4

[9] Kumar, P. and D.K. Singh., 2009, Use of amino acids and their combinations as attractant in bait formulations against the snail Lymnaea acuminata. Journal of Applied Bioscience., 35 (1), 63-6

[10] Kumar, P. and D. K. Singh., 2010, Amino acids and carbohydrates binary combination as an attractant in bait formulation against the snail Lymnaea acuminata. Malaysian Applied Biology.. 39 (1), 7-11

[11] Kumar, P., V. K. Singh, and D.K. Singh., 2011a, Combination of molluscicides with attractant carbohydrates and amino 
acids in bait formulation against the snail Lymnaea acuminata. European Review of Medical and Pharmacological Sciences., $15,550-555$

[12] Kumar, P., V. K. Singh, and D.K. Singh., 2011b, Bait formulation of molluscicides with attractant amino acid against the snail Indoplanorbis exustus. Pharmacologyonline., 3, $30-36$

[13] Tiwari, F., K. Singh, and D.K. Singh.,2008. Enzyme inhibition by different bait formulations in the nervous tissue of the snail Lymnaea. In: Environmental pollution and toxicology(B.D. Joshi; P.C. Joshi; Namita Joshi) Published by S.B. Najgia, Chapter XIII, pp 115-128.

[14] Kumar, P., V.K. Singh and D.K. Singh., 2010. Bait formulation containing molluscicides and attractant amino acids against the harmful snail Lymnaea acuminata. Drug Invention Today, 2(7), 358-361.

[15] Madsen, H., 1992, A comparative study on the food locating ability of Helisoma duryi, Biomphalaria comerunesis \& Bulinus truncates (Pulmonate planorbidae). Journal of Applied Ecology., 29, 70-8

[16] Tiwari, F. and D. K. Singh., 2004a, Attraction of amino acids by Lymnaea acuminata, snail host of Fasciola species. Brazilian Journal of Medical \& Biological Research., 37, 587-90

[17] Tiwari, F. and D. K. Singh., 2004b, Behavioural responses of the snail Lymnaea acuminata to carbohydrates in snail attractant pellets. Naturwissenschaften., 91, 378-80

[18] Bergmeyer, U. H., 1967, Methods of enzymatic analysis. Academic press, New York, pp. 1129

[19] Singh, D. K. and R. A. Agarwal., 1989, Toxicity of piperinyl butaoxide Carbaryl synergism on the snail Lymnaea acuminata. Inter. Revue Ges. Hydrobiol., 74, 689-699

[20] Ellman, G. L., K. D. Countney, V. Andres, and R. M. Feathstone., 1961, A new and rapid colorimetric determination of acetylcholinesterase activity. Biochem Pharmacol., 7, 88-95

[21] Singh, D. K. and R. A. Agarwal., 1983, In vivo and in vitro studies on synergism with anticholinesterase pesticides in the snail Lymnaea acuminata. J. Arch. Environ. Contam. Toxicol., 12, 483-487
[22] Sokal, R. R. and F. J. Rohlf., 2007, Introduction of biostatistics, W. H. Freeman, San Francisco., p. 185-207

[23] Kumar, P., V. K. Singh, and D.K. Singh., 2009, Kinetics of enzyme inhibition by active molluscicidal agents ferulic acid, umbelliferone, eugenol and limonene in the nervous tissue of snail Lymnaea acuminata. Phytotherapy Research., 23, 172-7

[24] Kumar, P., V. K. Singh, and D. K. Singh., 2011c, Bait formulations of molluscicides and their effects on biochemical changes in the ovotestis of snail Lymnaea acuminata (Mollusca; Gastropoda:Lymneidae), Rev. Inst. Med. Trop. Sao. Paulo., 53 (5), 271-275

[25] Pilo, B., M. B. Asnani, and R. V. Shah., 1972, Studies on wound healing and repair in pegion. III. Histochemical studies on acid and alkaline phosphatase activity during the process. L. Anim. Morphol. Physiol., 19, 205-212

[26] Timmermans, L.P.M., 1969, Studies on shell formation in mollusks. Netherland J. of Zool., 19, 17-36

[27] Ibrahim, A. M., M. G. Higazi. and E. S. Demian., 1974, Histochemical localization of alkaline phosphatase activity in the alimentary tract of the snail Marisa coruarielis (1). Bull. Zool. Soc. Egypt., 26, 94-105

[28] Singh, K. and D. K. Singh., 1995, Effect of Azadirachta indica (Neem) on the biochemical parameters in the ovotestis of Lymnaea acuminata. Malaysia Applied Biology., 26(2), 7-11

[29] Vorbrodt, A., 1959, The role of phosphate in intracellular metabolism, postepy. Hig. Med. DOSW., 13, 200-206

[30] Matsumura, F., 1985, Toxicology of Insecticides, $2^{\text {nd }}$ Ed. Plenum Press, New York

[31] Bullock, T. H., R. Orkand, and A. Grinnella., 1977, In: Introduction to nervous system (D, Kennedy Ed.) W. H. Freeman and company, San Francisco.

[32] O' Brien, R. D., 1976, Acetylcholinesterase and its inhibition in insecticide biochemistry and physiology (C. F. Wilkinson, ed), Plenum press, New York., pp. 271-273

[33] Sahib, K. A. and Rao, I. R., 1980, Toxicity of malathion to the freshwater fish, Tilapia massambica. Bull. Environ. Contam. Toxicol., 24, 870-874 